\title{
Effect of phenobarbitone and starvation on hepatotoxicity in rats exposed to carbon disulphide vapour
}

\author{
L. MAGOS and W. H. BUTLER \\ Medical Research Council Laboratories, Toxicology Unit, Woodmansterne Road, \\ Carshalton, Surrey
}

\begin{abstract}
Magos, L., and Butler, W. H. (1972). Brit. J. industr. Med., 29, 95-98. Effect of phenobarbitone and starvation on hepatotoxicity in rats exposed to carbon disulphide vapour. Male albino rats given 80 and $50 \mathrm{mg} / \mathrm{kg}$ phenobarbitone sodium by intraperitoneal injection 24 and 18 hours before 4-hour exposure to $2.0 \mathrm{mg} / \mathrm{l}$ carbon disulphide $\left(\mathrm{CS}_{2}\right)$ developed hydropic degeneration in the centrilobular zone of the liver. Less marked in some fed animals, this change became general and more severe in rats starved for 24 hours before exposure. On incomplete diets with excess of sucrose or animal fat, the frequency and severity of lesions were somewhat between those observed in starved and fed rats. This observation calls attention to the possibility that in certain circumstances of industrial exposure, such as nutritional deficiency plus drug treatment, $\mathbf{C S}_{\mathbf{2}}$ might cause disturbances in liver function.
\end{abstract}

Carbon disulphide $\left(\mathrm{CS}_{2}\right)$ is not recognized as an hepatotoxic agent. Rabbits exposed daily-five days a week-for many weeks until a partial loss of control over voluntary movements of the hind legs appeared did not show any pathological changes in the liver (Cohen et al., 1959). An oral dose of $1 \mathrm{mg} / \mathrm{kg} \mathrm{CS}$ given to rats produced only an increase in fat in the periportal zone. When the same dose of $\mathrm{CS}_{2}$ was given to rats pretreated with phenobarbitone, extensive centrilobular zone necrosis appeared (Bond, Butler, De Matteis, and Barnes, 1969). However, these animals were subjected not only to phenobarbitone pretreatment but also to starvation as food was withdrawn 24 hours before exposure to avoid the gastric effect of $\mathrm{CS}_{2}$ on food and food consumption.

The purpose of the present work was to investigate whether liver damage can be induced in phenobarbitone-pretreated rats by inhalation exposure to $\mathrm{CS}_{2}$. Inhalation exposure also made it possible to study the effect of starvation on liver damage in phenobarbitone-pretreated rats exposed to $\mathbf{C S}_{2}$. Starvation significantly decreased the urinary excretion of both $\mathrm{CS}_{2}$ and its bivalent sulphur metabolites in exposed rats (Magos, 1972) and starvation may have contributed to the development of liver necrosis in phenobarbitone-pretreated animals (Bond et al., 1969). As $\mathrm{CS}_{2}$ can be converted in the body to dithiocarbamate type compounds (Souček, 1957) and dithiocarbamate is partly metabolized to $\mathrm{CS}_{2}$ (Strömme, 1965) the effect of diethyldithiocarbamate on the liver was also investigated in some of the experiments.

\section{Methods}

Male albino rats of Porton-Wistar strain (200-220 g) bred in this colony were used. Phenobarbitone sodium (BDM) was given intraperitoneally in a dose of $80 \mathrm{mg} / \mathrm{kg}$ 24 hours and $50 \mathrm{mg} / \mathrm{kg} 18$ hours before 4-hour exposure to $2 \mathrm{mg} / \mathrm{kg} \mathrm{CS}$ or 18 and 23 hours before the administration of $500 \mathrm{mg} / \mathrm{kg}$ sodium diethyldithiocarbamate (DDC; Hopkin and Williams). Animals were exposed to $\mathrm{CS}_{2}$ in a vertical type inhalation chamber (Magos, Emery, Lock, and Firmager, 1970). From the starved group, food was withdrawn 24 hours before exposure or before DDC. From the fed animals, food was withdrawn at the beginning of exposure to $\mathrm{CS}_{2}$ or 5 hours before the injection of DDC. Sucrose or fat fed animals were given only sucrose or only pork lard in the last 24 hours before exposure. Water was available ad libitum to all animals except when they were in the inhalation 
chamber. Animals were killed by decapitation, usually 18 hours after the end of exposure or the administration of DDC, and the livers were removed, weighed, and fixed in formol-alcohol or formol saline. Paraffin sections prepared in the usual fashion were stained with Harris' haematoxylin and eosin, and in some cases frozen sections were stained with oil red 0 for fat.

The liver sections were examined without knowledge of the treatment and were given a score indicating the severity of the damage. Sections scored as 0 were indistinguishable from normal. A score of 1 indicated a few hydropic cells in the region of the central vein (Fig. 1) while a score of 2 indicated that in the order of half of each lobule was changed to hydropic cells (Fig. 2). A score of 3 was used when only a rim of hepatic parenchymal cells remained in the vicinity of the portal tracts surrounding the more centrilobular hydropic cells.

\section{Results}

The character of the histological change at 18 hours was similar in all the rats treated with phenobarbitone and exposed to $\mathrm{CS}_{2}$ but the extent of the damage was variable. The main change in the hepatic parenchymal cells of the centrilobular area was a swelling of the cytoplasm similar to that of a hydropic degeneration with the nuclei of those cells normal in appearance. However, scattered throughout the zone of hydropic degeneration were pyknotic nuclei, and nuclei in which there was margination of the chromatin or fragmentation of the nucleus. The central veins were normal and no inflammatory reaction was seen. In the periportal zone the surviving hepatic cells were normal except for an accumulation of some lipid, not seen in the centrilobular area, and slightly greater than that seen in the unexposed starved animals with or without phenobarbitone treatment. The portal tracts were normal. Within any liver the extent of the change was reasonably uniform.

Table 1 shows the degree of liver damage, scored as described above, produced by 4-hour exposure to $\mathrm{CS}_{2}(2.0 \mathrm{mg} / \mathrm{l})$ in phenobarbitone-pretreated rats and that phenobarbitone was essential for the development of liver damage in starved rats exposed to $\mathrm{CS}_{2}$ or treated with diethyldithiocarbamate. When $500 \mathrm{mg} / \mathrm{kg}$ DDC was given to phenobarbitonepretreated rats before exposure to $\mathrm{CS}_{2}$ (group 5) the liver damage was more severe than in either $\mathrm{CS}_{2}$-exposed (group 2) or DDC-treated rats (group 4). The extent of liver damage in the DDC-treated rats (group 4) was less severe than in $\mathrm{CS}_{2}$-exposed rats (group 2). There is some variation within groups as indicated by the scoring of the histological

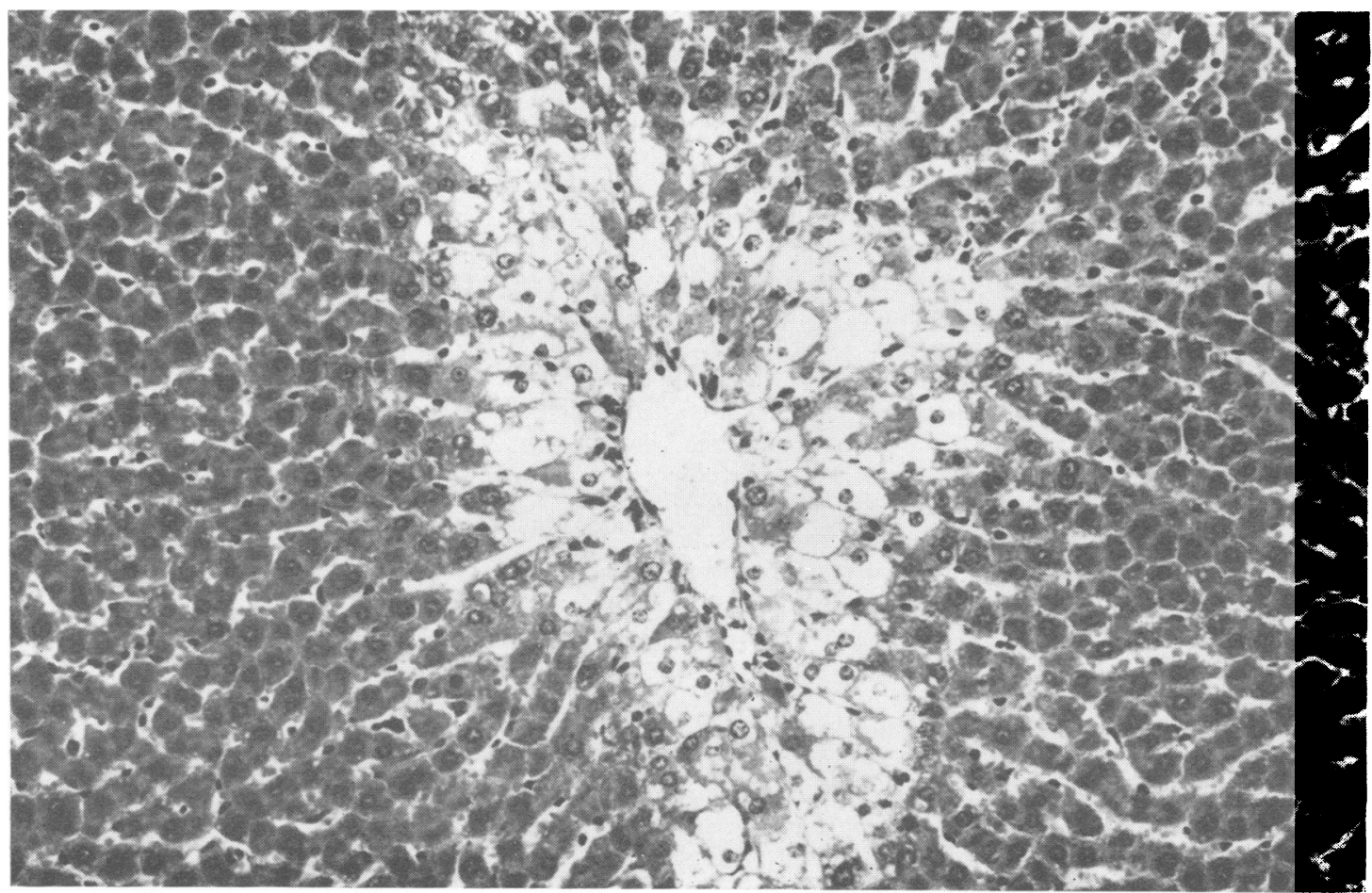

FIG. 1. Liver of rat, pretreated with phenobarbitone and starved, killed 24 hours after exposure to carbon disulphide showing a centrilobular zone of hydropic degeneration. Grade 1 lesion. H. and E. $\times 130$. 


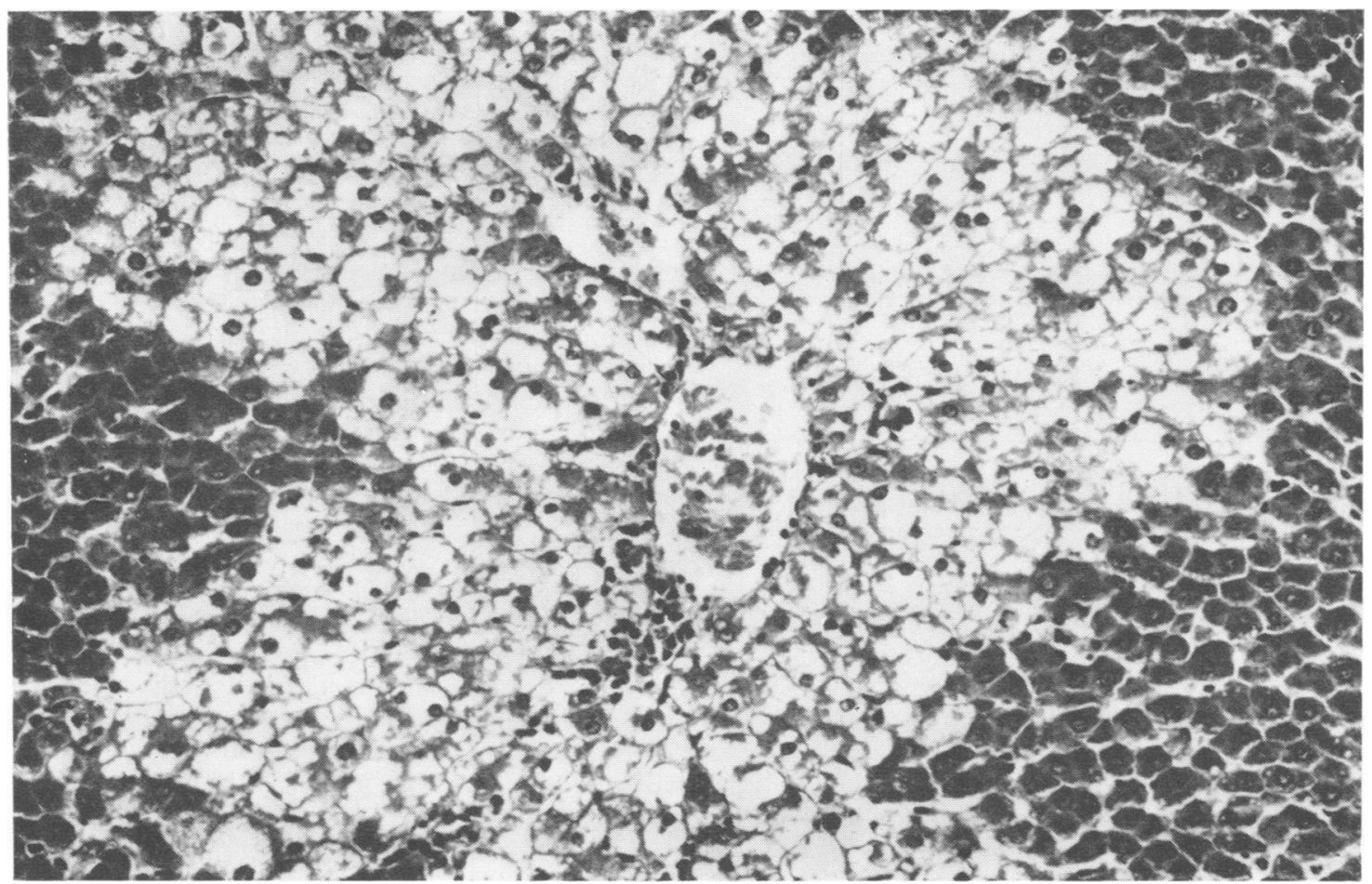

FIG. 2. Liver of rat, pretreated with phenobarbitone and starved, killed 24 hours after exposure to carbon disulphide showing extensive hydropic degeneration involving about one-half of the lobule. Grade 2 lesion. H. and E. $\times 130$.

\section{TABLE 1}

EfFect of Phenobarbitone on Liver Damage in StaRVed MALE RATS EXPOSED 4 HOURS to $2.0 \mathrm{mg} / \mathrm{l}$ $\mathrm{CS}_{2}$ OR/AND TREATED WITH $500 \mathrm{mg} / \mathrm{kg}$ SODIUM DiETHYLDITHIOCARBAMATE (DDC).

\begin{tabular}{|c|c|c|c|c|c|c|c|c|}
\hline \multirow[t]{2}{*}{ Group } & \multicolumn{3}{|c|}{ Treatment } & \multirow[t]{2}{*}{$\begin{array}{l}\text { No. of } \\
\text { rats }\end{array}$} & \multicolumn{4}{|c|}{$\begin{array}{c}\text { Grade of liver } \\
\text { damage }\end{array}$} \\
\hline & $P h$ & $D D C$ & $C S_{2}$ & & 0 & 1 & 2 & 3 \\
\hline 1 & - & - & + & 16 & 16 & - & - & - \\
\hline 2 & + & - & + & 6 & - & 1 & 5 & - \\
\hline 3 & - & + & + & 5 & 5 & - & - & - \\
\hline 4 & + & + & - & 6 & 1 & 4 & 1 & - \\
\hline 5 & + & + & + & 6 & - & - & 1 & 5 \\
\hline 6 & - & - & - & 8 & 8 & - & - & - \\
\hline
\end{tabular}

Phenobarbitone sodium $(\mathrm{Ph})$ in a dose of 80 and $50 \mathrm{mg} / \mathrm{kg}$ was given 24 and 18 hours before exposure or the administration of DDC. Food was withdrawn 24 hours before exposure. Animals were killed 24 hours after injection or the beginning of exposure. lesions. The differences between the severity of the lesions as illustrated in Figs. 1 and 2 is such that in spite of the difficulties in scoring degrees of damage these groups are distinct.

Feeding provided a partial protection against the hepatotoxic effect of $\mathrm{CS}_{2}$ in phenobarbitone-pretreated rats. Only 10 of the 30 fed animals developed any discernible liver lesions compared with 28 of the 30 starved rats (Table 2). When incomplete diets were given in the form of sucrose or animal fat, the frequency and severity of the lesions were somewhat between those observed in starved and fed animals.

One-hour $\mathrm{CS}_{2}$ exposure produced liver lesions in five of the eight starved, phenobarbitone-treated rats killed 21 hours after exposure, though in four animals damage in the liver scored only $1+$. There was no difference in liver damage between animals exposed 3 or 4 hours to $2.0 \mathrm{mg} / 1 \mathrm{CS}_{2}$. An interval between exposure and sacrifice was essential for the development of the hepatic lesion as none of the five starved, phenobarbitone-pretreated rats killed immediately after exposure showed signs of liver damage. 
TABLE 2

EfFEct of Starvation OR INCOMPlete FeEding on Liver Damage in Phenobarbitone-Pretreated MALE RATS EXPOSED 4 HOURS TO $2.0 \mathrm{mg} / \mathrm{l} \mathrm{CS}_{2}$

\begin{tabular}{|c|c|c|c|c|c|c|}
\hline \multicolumn{3}{|c|}{ Nutritional condition } & \multirow[t]{2}{*}{$\begin{array}{l}\text { No. of } \\
\text { rats }\end{array}$} & \multicolumn{3}{|c|}{$\begin{array}{l}\text { Grade of liver } \\
\text { damage }\end{array}$} \\
\hline & & & & 0 & 1 & 2 \\
\hline $\begin{array}{l}\text { Fed } \\
\text { Fasted } \\
\text { Sucrose-fed } \\
\text { Fat-fed }\end{array}$ & $\begin{array}{l}. \\
\cdots \\
\cdots \\
.\end{array}$ & 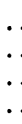 & $\begin{array}{r}30 \\
30 \\
15 \\
6\end{array}$ & $\begin{array}{r}20 \\
2 \\
2 \\
1\end{array}$ & $\begin{array}{r}10 \\
10 \\
6 \\
4\end{array}$ & $\begin{array}{r}- \\
18 \\
7 \\
:\end{array}$ \\
\hline
\end{tabular}

Food was withdrawn 24 hours before exposure when the first phenobarbitone dose $(80 \mathrm{mg} / \mathrm{kg})$ was given; 6 hours later phenobarbitone treatment was repeated by giving a $50 \mathrm{mg} / \mathrm{kg}$ dose. Rats were killed 24 hours after the beginning of exposure.

\section{Discussion}

We have confirmed the observation that $\mathrm{CS}_{2}$ can only induce liver damage in male rats which have been pretreated with phenobarbitone but the dose by inhalation is considerably less than the $1.0 \mathrm{ml} / \mathrm{kg}$ per os given (Bond et al., 1969). In rats exposed to $2.0 \mathrm{mg} / 1 \mathrm{CS}_{2}$ for 4 hours, even were all the $\mathrm{CS}_{2}$ which reached the alveoli to be taken up by the circulating blood, the amount absorbed can be no more than $100 \mathrm{mg} / \mathrm{kg}$. Nevertheless the histological changes in the starved animals exposed to vapour are comparable to those in rats given $\mathrm{CS}_{2}$ per os.

The toxic reaction in the liver can only be demonstrated when exposure follows phenobarbitone treatment; the reaction is aggravated by starvation. The observation that starvation increases the effect of phenobarbitone on cytochrome P-450 concentration in the liver (Greim, 1970) offers a very attractive hypothesis for the explanation of phenobarbitone effect on $\mathrm{CS}_{2}$ hepatotoxicity. Phenobarbitone might increase the transformation of $\mathrm{CS}_{2}$ to a toxic metabolite through the induction of drugmetabolizing enzymes, as has been suggested for $\mathrm{CCl}_{4}$, a rather unreactive compound. However, this hypothesis presents some difficulties. Compared with carbon tetrachloride, $\mathrm{CS}_{2}$ is an extremely reactive compound and there is no evidence of the existence of a more reactive metabolite. Furthermore, the urinary excretion of $\mathrm{CS}_{2}$ and its bivalent metabolites is not altered by phenobarbitone treatment but only by starvation (Magos, 1972). Finally, in agreement with the metabolic pathway of DDC, which is mainly detoxified by conjugation with glucuronic acid and to a smaller extent decomposed to $\mathrm{CS}_{2}$ (Strömme, 1965), DDC is able to produce an hepatotoxic effect in fasted phenobarbitone-treated rats, but even a $500 \mathrm{mg} / \mathrm{kg}$ dose resulted in only slight changes compared with those observed in rats exposed to $\mathrm{CS}_{2}$. Consequently, it seems worthwhile to consider the possibitity that $\mathrm{CS}_{\mathbf{2}}$ and not one of its metabolites is the hepatotoxic agent and that starvation aggravates hepatotoxicity by promoting the retention of $\mathrm{CS}_{2}$ or its additive reaction with cell constituents.

The practical implications of these experiments are that in certain conditions of exposure to the vapours of $\mathrm{CS}_{2}$ hepatic damage may result. Thus the effects of an occupational exposure dose might be changed by factors such as the nutritional state or the administration of therapeutic drugs. Though the $\mathrm{CS}_{2}$ concentration was very high in these experiments compared with the maximum allowable concentration $(0.06 \mathrm{mg} / \mathrm{l})$, one must consider that on the one hand the exposure time was extremely short and on the other hand much higher concentrations than the MAC value have been reported from industry (Brieger and Teisinger, 1967).

We wish to thank Mrs. A. R. Green for technical assistance.

\section{References}

Bond, E. J., Butler, W. H., De Matteis, F., and Barnes, J. M. (1969). Effects of carbon disulphide on the liver of rats. Brit. J. industr. Med., 26, 335-337.

Brieger, H., and Teisinger, I. (editors) (1967). Toxicology of Carbon Disulphide: Proceedings of a Symposium, Prague, 1966. Excerpta Medica Foundation, Amsterdam.

Cohen, A. E., Scheel, L. D., Kopp, J. F., Stockel, F. R., Keenan, R. G., Mountain, J. T., and Paulus, H. J. (1959). Biochemical mechanisms in chronic carbon disulfide poisoning. Amer. industr. Hyg. Ass. J., 20, 303-323.

Greim, H. (1970). Synthesesteigerung und Abbauhemmung bei der Vermehrung der mikrosomalen Cytochrome $\mathrm{P}-450$ and b-5 durch Phenobarbital. Naunyn-Schmiedeberg's Arch. Pharmak., 266, 261-275.

Magos, L. (1972). The relevancy of bivalent sulphur excretion to carbon disulphide exposure in different metabolic conditions. Brit.J. industr. Med., 29, 90-94.

, Emery, R. C., Lock, R. D., and Firmager, B. G. (1970). A vertical-type constant flow inhalation chamber for rats. Lab. Pract., 19, 725-727.

Souček, B. (1957). Unwandlung von Schwefelkohlenstoff im Organismus. J. Hyg. Epidem. Microbiol. Immun. (Praha), 1, 10-22.

Strömme, J. H. (1965). Metabolism of disulfiram and diethyldithiocarbamate in rats with demonstration of an in vivo ethanol-induced inhibition of the glucuronic acid conjugation of the thiol. Biochem. Pharmacol., 14, 393-410.

Received for publication April 3, 1971 